\title{
Estimating changes in Scottish soil carbon stocks using ECOSSE. I. Model description and uncertainties
}

\author{
Jo Smith ${ }^{1, *}$, Pia Gottschalk1 ${ }^{1}$, Jessica Bellarby ${ }^{1}$, Stephen Chapman ${ }^{2}$, Allan Lilly ${ }^{2}$, \\ Willie Towers ${ }^{2}$, John Bell ${ }^{2}$, Kevin Coleman ${ }^{3}$, Dali Nayak ${ }^{1}$, Mark Richards ${ }^{1}$, Jon Hillier ${ }^{1}$, \\ Helen Flynn ${ }^{1}$, Martin Wattenbach ${ }^{1}$, Matt Aitkenhead ${ }^{1,2}$, Jagadeesh Yeluripati ${ }^{1}$, Jenny \\ Farmer $^{1}$, Ronnie Milne ${ }^{4}$, Amanda Thomson ${ }^{4}$, Chris Evans $^{5}$, Andy Whitmore ${ }^{3}$, \\ Pete Falloon ${ }^{6}$, Pete Smith ${ }^{1}$
}

\author{
${ }^{1}$ Institute of Biological \& Environmental Sciences, School of Biological Science, University of Aberdeen, 23 St. Machar Drive \\ Aberdeen AB24 3UU, UK \\ ${ }^{2}$ Macaulay Land Use Research Institute, Craigiebuckler, Aberdeen AB15 8QH, UK \\ ${ }^{3}$ Rothamsted Research, Harpenden, Hertfordshire AL5 2JQ, UK \\ ${ }^{4}$ Centre for Ecology \& Hydrology, Bush Estate, Penicuik, Midlothian EH26 0QB, UK \\ ${ }^{5}$ Centre for Ecology \& Hydrology, Environment Centre Wales, Deiniol Road, Bangor, Gwynedd LL57 2UW, UK \\ ${ }^{6}$ Met Office Hadley Centre, FitzRoy Road, Exeter, Devon EX1 3PB, UK
}

\begin{abstract}
To predict the response of C-rich soils to external change, models are needed that accurately reflect the conditions of these soils. Estimation of Carbon in Organic Soils-Sequestration and Emissions (ECOSSE) is a model that allows simulations of soil $\mathrm{C}$ and $\mathrm{N}$ turnover in both mineral and organic soils using only the limited meteorological, land-use and soil data that is available at the national scale. Because it is able to function at field as well as national scales if appropriate input data are used, field-scale evaluations can be used to determine uncertainty in national simulations. Here we present an evaluation of the uncertainty expected in national-scale simulations of Scotland, using data from the National Soil Inventory of Scotland. This data set provides measurements of $\mathrm{C}$ change for the range of soils, climates and land-use types found across Scotland. The simulated values show a high degree of association with the measurements in both total $\mathrm{C}$ and change in $\mathrm{C}$ content of the soil. Over all sites where land-use change occurred, the average deviation between the simulated and measured values of percentage change in soil $\mathrm{C}$ was less than the experimental error $(11 \%$ simulation error, $53 \%$ measurement error). This suggests that the uncertainty in the national-scale simulations will be $\sim 11 \%$. Only a small bias in the simulations was observed compared to the measured values, suggesting that a small underestimate of the change in soil $\mathrm{C}$ should be expected at the national scale $(-4 \%)$.
\end{abstract}

KEY WORDS: Organic soils · Dynamics simulation modelling $\cdot$ Changes in soil C stocks $\cdot$ Land-use change $\cdot$ Uncertainty $\cdot$ National-scale simulations

\section{INTRODUCTION}

Climate change, held to be largely driven by increases in greenhouse gas (GHG) emissions, is one of the most serious threats facing our planet (IPCC 2007), and is of concern at international, UK and devolved administration levels (Scottish Government 2010, UK Government 2010, Welsh Assembly Govern- ment 2010). Accurate predictions of the effects of changes in climate and land use on GHG emissions are vital for informing land use policy.

Peatlands, characterized as carbon (C)-rich soils, cover approximately 4 million $\mathrm{km}^{2}$ globally, with a total $\mathrm{C}$ stock estimated in 2008 to be $\sim 450 \mathrm{Pg} \mathrm{C}$ (Joosten 2009). This amounts to $18 \%$ of the $2500 \mathrm{Pg}$ C stored in all soils (Lal 2004). Peat is found across the planet, with Russia, 
Canada, Indonesia and the USA having the largest peatland areas, totaling just under 3 million $\mathrm{km}^{2}$ (Joosten 2009). Northern peatlands are the most important terrestrial C store, holding between 200 and $450 \mathrm{Pg} \mathrm{C}$ (Gorham 1991, Turunen et al. 2002). The rate of $\mathrm{C}$ accumulation over the last 6000 to 8000 yr has been estimated to be between 20 and $30 \mathrm{~g} \mathrm{C} \mathrm{m}^{-2} \mathrm{yr}^{-1}$ (Gorham 1991, Vitt et al. 2000, Turunen et al. 2002, 2004), and over the Holocene, northern peatlands are estimated to have accumulated $\mathrm{C}$ at an average rate of $96 \mathrm{Mt} \mathrm{C} \mathrm{yr}^{-1}$, making peatlands not only a substantial store of $\mathrm{C}$, but also a large potential sink for atmospheric C (Gorham 1991). Highly organic soils can make a significant contribution to national GHG emissions. For example, $15 \%$ of Scotland's total emissions come from land-use changes on Scotland's C-rich soils (Smith et al. 2007).

To predict the response of organic soils to external change, models are needed that accurately reflect the conditions of C-rich soils, including peats and those soils with thin $(<50 \mathrm{~cm})$ organic layers overlying mineral material (organo-mineral soils). Most models currently used to predict differences in soil $\mathrm{C}$ and nitrogen (N) caused by these changes have been derived from models originally developed for mineral soils (Smith 2001). None of these models is entirely satisfactory for describing what happens to organic soils following land-use change, due to the omission of processes that are important in organic soils (Smith et al. 2007). For example, national-scale simulations of GHG emissions using the RothC soil organic C model (Coleman \& Jenkinson 1996) provide unrealistic results for the majority of soils in Scotland due to the large proportion of highly organic soils (Smith et al. 2007). Here we present an assessment of the uncertainty of simulations from an example application of a new model designed to provide more accurate simulation of net change to soil $\mathrm{C}$ and $\mathrm{N}$ in response to changes in land use and climate in highly organic as well as mineral soils. This new model assumes that similar processes can occur in mineral and organic soils, but the extent of these processes is modified by the soil conditions. The uncertainty was estimated for national simulations of changes in soil C stocks in Scotland. Scotland is a relatively small country $\left(\sim 78000 \mathrm{~km}^{2}\right)$, and has soils ranging from $<1$ to almost $60 \%$ organic $\mathrm{C}$ content (Lilly et al. 2004); because of this it is ideal for the development of a dynamic model that simulates emissions from highly organic northern temperate soils, and which can ultimately be used in larger countries.

\section{THE ECOSSE APPROACH}

While a few models have been developed to describe deep peat formation and turnover (e.g. Clymo 1992), until recently, none had been developed that were suitable for examining the impacts of land-use and climate change on the types of thin organo-mineral soils with $<50 \mathrm{~cm}$ surface organic horizon that are often subject to land-use change (Smith et al. 2007). For example, because of their location, deeper peat soils in Scotland are usually under semi-natural land use and tend to undergo less land use change than the shallower organo-mineral soils, which tend to be more accessible for agriculture. The main aim of the model described here is to simulate the impacts of land-use and climate change on GHG emissions from these types of soils, as well as mineral and peat soils. The model is: (1) driven by commonly available meteorological, land-use and soil data, (2) able to predict the impacts of land-use and climate change on $\mathrm{C}$ and $\mathrm{N}$ stores in organic and mineral soils, and (3) able to function at national as well as field scales, thus allowing results to be used to directly inform policy decisions.

The new model, Estimating Carbon in Organic SoilsSequestration and Emissions (ECOSSE), was developed from concepts originally derived for mineral soils in the RothC (Jenkinson \& Rayner 1977, Jenkinson et al. 1987, Coleman \& Jenkinson 1996) and SUNDIAL (Bradbury et al. 1993, Smith et al. 1996a) models. Following these established models, ECOSSE uses a pool-type approach, describing soil organic matter (SOM) as pools of inert organic matter (IOM), humus (HUM), biomass (BIO), resistant plant material (RPM) and decomposable plant material (DPM) (Fig. 1a). A complete and detailed description of the structure and formulation of the ECOSSE model is given in Smith et al. (2010) (https://www.abdn. ac.uk/staffpages/uploads/soi450/ECOSSE\%20User\% 20manual\%20310810.pdf), so a succinct description including only the new components of the model is presented here. The main differences in the simulation of soil C dynamics in ECOSSE compared to RothC and SUNDIAL are given in Table 1.

All of the major processes of $\mathrm{C}$ and $\mathrm{N}$ turnover in the soil are included in the model, but each of the processes is simulated using only simple equations driven by readily available input variables, allowing the model to be applied at both field and national scales, without a great loss of accuracy. ECOSSE differs from RothC and SUNDIAL in the addition of descriptions of a number of processes and impacts that are not crucial in the mineral arable soils that these models were originally developed for. More importantly, ECOSSE differs from RothC and SUNDIAL in the way that it makes full use of the limited information that is available to run models at national scale. In particular, measurements of soil $\mathrm{C}$ are used to interpolate the activity of the SOM and the plant inputs needed to achieve those measurements. If data are available describing soil water, plant inputs, nutrient applications and timing of 

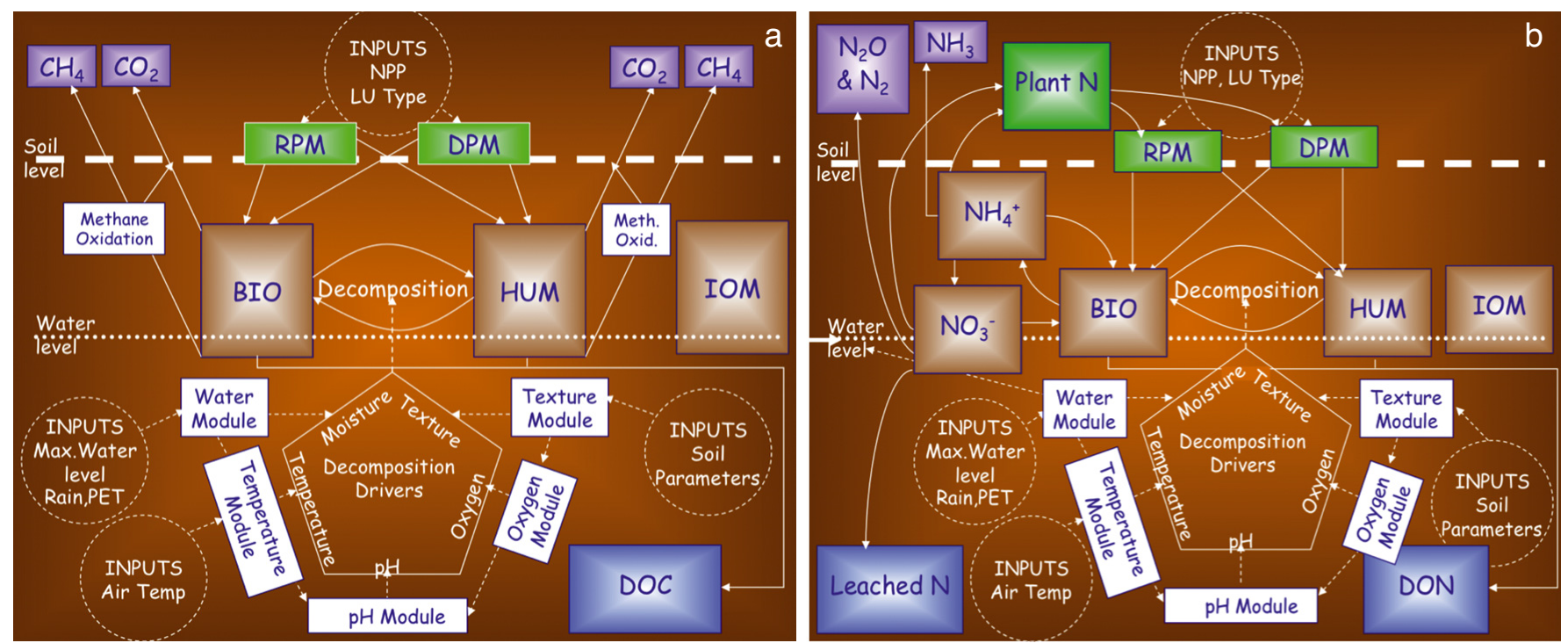

Fig. 1. Structure of the (a) carbon and (b) nitrogen components of ECOSSE. See https://www.abdn.ac.uk/staffpages/uploads/ soi450/ECOSSE\%20User\%20manual\%20310810.pdf for a detailed description of the model. Plant inputs enter the soil as RPM (resistant plant material) and DPM (decomposable plant material), and decompose into BIO ('biomass' or active organic matter) and HUM ('humus' or more slowly turning over soil organic matter). Organic matter that has become inert (IOM) is assumed to not contribute to the decomposition processes. Losses of $\mathrm{C}$ and $\mathrm{N}$ from the soil are gaseous $\left(\mathrm{CH}_{4}, \mathrm{CO}_{2}, \mathrm{~N}_{2} \mathrm{O}, \mathrm{N}_{2}\right.$ and $\left.\mathrm{NH}_{3}\right)$ and in solution (DOC: dissolved organic C, DON: dissolved organic N, and leached nitrate N). Solid arrows indicate flow of material. Dashed arrows indicate influence

Table 1. Differences in the simulation of soil carbon dynamics among ECOSSE, SUNDIAL and RothC models. DOC: dissolved organic carbon; DON: dissolved organic nitrogen; SOM: soil organic matter; HUM: humus; DPM: decomposable plant material; RPM: resistant plant material; $\mathrm{n} / \mathrm{a}$ : not applicable

\begin{tabular}{|c|c|c|c|}
\hline & $\begin{array}{c}\text { RothC } \\
\text { Carbon only } \\
\text { Field } \rightarrow \text { National }\end{array}$ & $\begin{array}{c}\text { SUNDIAL } \\
\text { Carbon and nitrogen } \\
\text { Field }\end{array}$ & $\begin{array}{c}\text { ECOSSE } \\
\text { Carbon and nitrogen } \\
\text { Field } \rightarrow \text { National }\end{array}$ \\
\hline \multicolumn{4}{|l|}{ Aerobic decomposition } \\
\hline Response to soil water & $\begin{array}{l}\text { Range }=\text { wilting point } \\
\text { to field capacity }\end{array}$ & $\begin{array}{l}\text { Range }=\text { wilting point } \\
\text { to field capacity }\end{array}$ & $\begin{array}{l}\text { Range }=\text { wilting point } \\
\text { to saturation }\end{array}$ \\
\hline Response to soil $\mathrm{pH}$ & $\mathrm{n} / \mathrm{a}$ & $\mathrm{n} / \mathrm{a}$ & Included \\
\hline \multicolumn{4}{|l|}{ Anaerobic decomposition } \\
\hline Response to temperature & $\mathrm{n} / \mathrm{a}$ & $\mathrm{n} / \mathrm{a}$ & Included \\
\hline Response to soil water & $\mathrm{n} / \mathrm{a}$ & $\mathrm{n} / \mathrm{a}$ & Included \\
\hline Response to soil pH & $\mathrm{n} / \mathrm{a}$ & $\mathrm{n} / \mathrm{a}$ & Included \\
\hline \multicolumn{4}{|l|}{ Soil $\mathbf{N}$} \\
\hline Stable C:N ratio & $\mathrm{n} / \mathrm{a}$ & Constant & Changes with soil $\mathrm{pH}$ \\
\hline $\begin{array}{l}\text { Layer structure for } \\
\text { solute movement }\end{array}$ & $\mathrm{n} / \mathrm{a}$ & Complex & $\begin{array}{l}\text { Uses } 5 \mathrm{~cm} \text { layers } \\
\text { throughout profile }\end{array}$ \\
\hline Leaching of DOC and DON & $\mathrm{n} / \mathrm{a}$ & $\mathrm{n} / \mathrm{a}$ & $\begin{array}{l}\text { Simulated by } \\
\text { piston flow }\end{array}$ \\
\hline Activity of SOM & $\begin{array}{l}\text { Pools and plant input } \\
\text { from equilibrium run } \\
\text { using soil C } \\
\text { Assumes soil is } \\
\text { at equilibrium }\end{array}$ & $\begin{array}{l}\text { Pools defined by } \\
\text { fixed proportions } \\
\text { Plant inputs estimated } \\
\text { from yield }\end{array}$ & $\begin{array}{l}\text { Pools and plant input } \\
\text { from steady state } \\
\text { run using soil C } \\
\text { Soils can be at equilibrium, } \\
\text { accumulating or degrading }\end{array}$ \\
\hline \multicolumn{4}{|l|}{ Land-use change } \\
\hline Physical protection & $\mathrm{n} / \mathrm{a}$ & $\mathrm{n} / \mathrm{a}$ & $\begin{array}{l}\text { Protected SOM release } \\
\text { from HUM to DPM } \\
\text { and RPM }\end{array}$ \\
\hline Establishment phase for new land use & $\mathrm{n} / \mathrm{a}$ & $\mathrm{n} / \mathrm{a}$ & Simple linear equation \\
\hline
\end{tabular}


Table 2. Parameters used in equations. BIO: biomass; DOC: dissolved organic carbon; DPM: decomposable plant material; HUM: humus; IOM: inert soil organic matter; RPM: resistant plant material. n/a: not applicable (no units)

\begin{tabular}{|c|c|c|}
\hline Parameter & Definition & Units \\
\hline$C_{1}$ & Fitted constant describing water content rate modifier for anaerobic decomposition & $\mathrm{n} / \mathrm{a}$ \\
\hline$c_{2}$ & Fitted constant describing water content rate modifier for anaerobic decomposition & timestep $^{-1}$ \\
\hline$C_{3}$ & Fitted constant describing $\mathrm{pH}$ rate modifier for anaerobic decomposition & $\mathrm{n} / \mathrm{a}$ \\
\hline$C_{4}$ & Fitted constant describing $\mathrm{pH}$ rate modifier for anaerobic decomposition & $\mathrm{n} / \mathrm{a}$ \\
\hline$C: N_{\mathrm{b}}$ & Stable C:N ratio of bacteria & $\mathrm{n} / \mathrm{a}$ \\
\hline$C: N_{\mathrm{f}}$ & Stable C:N ratio of fungi & $\mathrm{n} / \mathrm{a}$ \\
\hline$C: N_{\mathrm{s}}$ & Stable C:N ratio of BIO and HUM pools & $\mathrm{n} / \mathrm{a}$ \\
\hline $\mathrm{C}_{\text {in }}$ & Actual annual organic input & $\mathrm{kg} \mathrm{C} \mathrm{ha}^{-1}$ layer $^{-1}$ \\
\hline $\mathrm{C}_{\text {in, def }}$ & Default annual organic input & $\mathrm{kg} \mathrm{C} \mathrm{ha}^{-1}$ layer $^{-1}$ \\
\hline $\mathrm{C}_{\mathrm{IOM}}$ & $\mathrm{C}$ in the IOM pool & $\mathrm{kg} \mathrm{C} \mathrm{ha}^{-1}$ layer $^{-1}$ \\
\hline $\mathrm{C}_{\text {tot, meas }}$ & Measured total soil C & $\mathrm{kg} \mathrm{C} \mathrm{ha}^{-1}$ layer $^{-1}$ \\
\hline $\mathrm{C}_{\text {tot, sim }}$ & Simulated total soil C & $\mathrm{kg} \mathrm{C} \mathrm{ha}^{-1}$ layer $^{-1}$ \\
\hline$d_{\mathrm{b}}$ & Bulk density of soil in the $5 \mathrm{~cm}$ layer & $\mathrm{g} \mathrm{cm}^{-3}$ \\
\hline$k_{\text {pool }}$ & Rate constant for production of DOC from pool DPM, RPM, BIO, HUM & $d^{-1}$ \\
\hline$m^{\prime \prime}{ }_{\mathrm{c}}$ & Rate modifier due to crop cover for production of DOC & $\mathrm{n} / \mathrm{a}$ \\
\hline$m_{\mathrm{pH}}$ & Aerobic decomposition rate modifier due to soil $\mathrm{pH}$ & $\mathrm{n} / \mathrm{a}$ \\
\hline$m_{\mathrm{pH}}^{\prime}$ & Anaerobic decomposition rate modifier due to soil $\mathrm{pH}$ & $\mathrm{n} / \mathrm{a}$ \\
\hline$m / 1 / 1$ & Rate modifier due to soil $\mathrm{pH}$ for production of DOC & $\mathrm{n} / \mathrm{a}$ \\
\hline$m_{\mathrm{pH}, \min }$ & Minimum value for rate modifier according to $\mathrm{pH}$ & $\mathrm{n} / \mathrm{a}$ \\
\hline$m_{t}^{\prime}$ & Anaerobic decomposition rate modifier due to soil temperature & $\mathrm{n} / \mathrm{a}$ \\
\hline$m /{ }_{t}$ & Rate modifier due to soil temperature from production of DOC & $\mathrm{n} / \mathrm{a}$ \\
\hline$m_{\mathrm{w}}$ & Aerobic decomposition rate modifier due to soil water content & $\mathrm{n} / \mathrm{a}$ \\
\hline$m_{\mathrm{w}}^{\prime}$ & Anaerobic decomposition rate modifier due to soil water content & $\mathrm{n} / \mathrm{a}$ \\
\hline$m^{\prime \prime}{ }_{\mathrm{w}}$ & Rate modifier due to soil water content for production of DOC & $\mathrm{n} / \mathrm{a}$ \\
\hline$m_{\mathrm{w} 0}$ & Aerobic decomposition rate modifier due to soil water content at permanent wilting point & $\mathrm{n} / \mathrm{a}$ \\
\hline$p_{\mathrm{b}}$ & Proportion of bacteria in the BIO and HUM pools & $\mathrm{n} / \mathrm{a}$ \\
\hline$p_{\mathrm{b}, \min }$ & Minimum proportion of bacteria in the BIO and HUM pools & $\mathrm{n} / \mathrm{a}$ \\
\hline$p_{\mathrm{b}, \max }$ & Maximum proportion of bacteria in the BIO and HUM pools & $\mathrm{n} / \mathrm{a}$ \\
\hline$P_{\mathrm{C}}$ & Percent $\mathrm{C}$ in the soil layer & $\%$ \\
\hline$p_{\mathrm{f}}$ & Proportion of fungi in the BIO and HUM pools & $\mathrm{n} / \mathrm{a}$ \\
\hline $\mathrm{pH}$ & Soil pH & $\mathrm{n} / \mathrm{a}$ \\
\hline $\mathrm{pH}_{\mathrm{b}, \min }$ & Soil $\mathrm{pH}$ at which minimum soil bacteria occurs & $\mathrm{n} / \mathrm{a}$ \\
\hline $\mathrm{pH}_{\mathrm{b}, \max }$ & Soil $\mathrm{pH}$ at which maximum soil bacteria occurs & $\mathrm{n} / \mathrm{a}$ \\
\hline $\mathrm{pH}_{\max }$ & Critical threshold $\mathrm{pH}$ below which rate of aerobic decomposition starts to decrease & $\mathrm{n} / \mathrm{a}$ \\
\hline $\mathrm{pH}_{\min }$ & $\mathrm{pH}$ at which rate of aerobic decomposition is at minimum rate & $\mathrm{n} / \mathrm{a}$ \\
\hline$P_{\mathrm{K}}$ & Clay content in the $5 \mathrm{~cm}$ layer & $\%$ \\
\hline$P_{\mathrm{s}}$ & Silt content of the $5 \mathrm{~cm}$ layer & $\%$ \\
\hline$T$ & Mean air temperature for the period in the timestep & ${ }^{\circ} \mathrm{C}$ \\
\hline$\theta_{\mathrm{c}}$ & Calculated amount of water held in a layer above the permanent wilting point & $\mathrm{mm}_{\text {layer }}^{-1}$ \\
\hline$\theta_{\mathrm{f}}$ & Amount of water held in a layer between field capacity and the permanent wilting point & mm layer ${ }^{-1}$ \\
\hline$\theta_{\mathrm{s}}$ & Amount of water held in a layer between saturation and the permanent wilting point & mm layer ${ }^{-1}$ \\
\hline
\end{tabular}

management operations, these can be used to drive the model and so better apportion the factors determining the interpolated activity of the SOM. However, if any of this information is missing, the model can still provide adequate simulations of SOM turnover, although the impact of changes in conditions will be estimated with less accuracy due to the reduced detail of the inputs.

\subsection{Aerobic decomposition}

During the decomposition process, ECOSSE assumes material is exchanged between the SOM pools according to first-order rate equations, characterized by a specific rate constant for each pool, and modified according to rate modifiers dependent on the tempera- ture, water content, plant cover and $\mathrm{pH}$ of the soil. As in the RothC and SUNDIAL models, the impact of soil texture on SOM decomposition is accounted for not through a rate modifier, but in the partitioning of decomposing organic matter into the BIO and HUM pools, thus simulating the effect of clay minerals on the physical protection of SOM. Under aerobic conditions, the decomposition process results in gaseous losses of $\mathrm{CO}_{2}$ i under anaerobic conditions, methane $\left(\mathrm{CH}_{4}\right)$ losses become significant. The ECOSSE description of decomposition differs from RothC and SUNDIAL in the response of aerobic decomposition to soil water content and the incorporation of a $\mathrm{pH}$ rate modifier.

Below field capacity, the response of aerobic decomposition to soil water content follows the relationship given for SUNDIAL by Bradbury et al. (1993). Between field capacity and saturation, the response of aerobic 
decomposition to soil water content includes a linear reduction in the rate of decomposition. When the water content of the soil is above field capacity, the aerobic rate modifier due to soil water content $\left(\mathrm{m}_{w}\right)$ is given by:

$$
m_{\mathrm{w}}=1-\frac{\left(\left(1-m_{\mathrm{w} 0}\right) \times\left(\theta_{\mathrm{c}}-\theta_{\mathrm{f}}\right)\right)}{\theta_{\mathrm{s}}-\theta_{\mathrm{f}}}
$$

where $m_{\mathrm{w} 0}$ is the rate modifier at permanent wilting point, and $\theta_{\mathrm{c}}$ is the calculated soil water content, $\theta_{\mathrm{s}}$ is the amount of water at saturation and $\theta_{\mathrm{f}}$ is the amount of water at field capacity, all above the permanent wilting point in mm layer $^{-1}$ (note that all parameters are listed and defined in Table 2). $\theta_{\mathrm{c}}$ is calculated as described in Bradbury et al. (1993). If the water held between field capacity and permanent wilting point $\left(\theta_{\mathrm{s}}\right)$ is not known, it can be calculated for each layer from the simulated soil C content $\left(\mathrm{C}_{\mathrm{tot}, \mathrm{sim}}\right)$ and the percent clay content $\left(P_{\mathrm{K}}\right)$ using the following pedotransfer function (Smith et al. 2010)

$$
\theta_{\mathrm{s}}=\left(0.0002 \times \mathrm{C}_{\mathrm{tot}, \mathrm{sim}}\right)+\left(0.25 \times P_{\mathrm{K}}\right)
$$

The aerobic decomposition rate modifier for $\mathrm{pH}$ shows a linear response, proceeding at an optimum rate (rate modifier $m_{\mathrm{pH}}=1$ ) until the $\mathrm{pH}$ falls below a critical threshold $\left(\mathrm{pH}_{\max }\right)$, after which the rate of decomposition declines linearly to a minimum rate (rate modifier $\left.m_{\mathrm{pH}}=m_{\mathrm{pH}, \min }\right)$ at $\mathrm{pH}_{\min }$ :

$$
m_{\mathrm{pH}}=m_{\mathrm{pH}, \min }+\left(1-m_{\mathrm{pH}, \min }\right)+\left(\frac{\mathrm{pH}-\mathrm{pH}_{\text {min }}}{\mathrm{pH}_{\max }-\mathrm{pH}_{\min }}\right)
$$

This is a simplification of the approach used in many models (e.g. Parton et al. 1996, Walse et al. 1998, Leifeld et al. 2008) that employ a sigmoid relationship. A linear approach was chosen because it allows more intuitive parameter selection than is possible for a sigmoid curve and differs from the sigmoid relationship by only a small amount at the points where the sigmoid curve asymptotes. The value of $m_{\mathrm{pH}, \mathrm{min}}$ was set to 0.2 . The values of $\mathrm{pH}_{\min }$ and $\mathrm{pH}_{\max }$ could be site specific, but for the national simulations these evaluations were set to 2 and 5, respectively, to be consistent with the relationship used by Walse et al. (1998).

\subsection{Anaerobic decomposition}

Anaerobic decomposition is not included in RothC or SUNDIAL, but is described in ECOSSE in a similar way to aerobic decomposition, using rate modifiers that are set according to relationships formulated for the anaerobic decomposition process. A proportion of the $\mathrm{CH}_{4}$ produced is oxidised back to $\mathrm{CO}_{2}$ depending on transportation of $\mathrm{CH}_{4}$ in plants, the rate of diffusion through the soil and the thickness of the aerobic region crossed by the $\mathrm{CH}_{4}$. Following the model of Kettunen
(2003), the temperature rate modifier for anaerobic decomposition $\left(m_{t}^{\prime}\right)$ is given by the same equation that is used for aerobic decomposition:

$$
m_{\mathrm{t}}^{\prime}=\frac{47.91}{\exp (125 / T+18.27)+1}
$$

where $T$ is the air temperature $\left({ }^{\circ} \mathrm{C}\right)$.

The anaerobic decomposition rate modifier for soil water content $\left(\mathrm{m}_{\mathrm{w}}{ }_{\mathrm{w}}\right)$ increases exponentially for a soil above field capacity according to the following equation:

$$
m_{\mathrm{w}}^{\prime}=c_{2} \exp \left(\left(c_{1} \times\left(\theta_{\mathrm{f}}-\theta_{\mathrm{s}}\right)\right)-1\right)
$$

where $\theta_{\mathrm{f}}$ is the amount of water held between field capacity and the permanent wilting point $\left(\mathrm{mm} \mathrm{layer}^{-1}\right)$, $\theta_{\mathrm{s}}$ is the amount of water held between saturation and permanent wilting point $\left(\mathrm{mm} \mathrm{layer}^{-1}\right)$, and $c_{1}$ and $c_{2}$ are fitted constants $\left(c_{1}=0.5 \mathrm{~d}^{-1}\right.$ and $\left.c_{2}=\frac{1}{\exp \left(\left(0.5 \times \theta_{\mathrm{s}}\right)-1\right)} \mathrm{d}^{-1}\right)$.

The anaerobic rate modifier for soil $\mathrm{pH}\left(\mathrm{m}_{\mathrm{pH}}^{\prime}\right)$ is more complex and follows a sigmoid relationship after measurements by Garcia et al. (2000) and Wang et al. (1993):

$$
m_{\mathrm{pH}}^{\prime}=\left(1.0^{1 / c_{4}}+\exp \left(c_{3} \times \mathrm{pH}\right)\right)^{c_{4}}
$$

where $c_{3}$ and $c_{4}$ are fitted constants and $\mathrm{pH}$ is the soil $\mathrm{pH}$.

\subsection{Soil $\mathbf{N}$}

The $\mathrm{N}$ content of the soil follows the decomposition of SOM (Fig. 1b), with a stable C:N ratio defined for the BIO and HUM pools and $\mathrm{N}$ being either mineralized or immobilized to maintain that ratio. ECOSSE differs from SUNDIAL in that the stable $\mathrm{C}: \mathrm{N}$ ratio changes with soil $\mathrm{pH}$, whereas SUNDIAL uses a constant value of 8. This represents the changes in the proportion of fungi in the soil that occur as the pH falls (Bardgett \& McAlister 1999). The stable C:N ratio $\left(C: N_{\mathrm{s}}\right)$ is given by the proportion of non-fungal organisms (such as bacteria, actinomycetes and Archaea) in BIO pools $\left(p_{\mathrm{b}}\right)$, the stable $C: N$ ratio of the non-fungal organisms $\left(C: N_{b}\right)$, the proportion of fungi $\left(p_{\mathrm{f}}\right)$ and the stable $\mathrm{C}: \mathrm{N}$ ratio of fungi $\left(C: N_{\mathrm{f}}\right)$ :

$$
C: N_{\mathrm{s}}=\left(p_{\mathrm{b}} \times C: N_{\mathrm{b}}\right)+\left(p_{\mathrm{f}} \times C: N_{\mathrm{f}}\right)
$$

The proportion of non-fungal organisms $\left(p_{\mathrm{b}}\right)$ is determined from the soil $\mathrm{pH}(\mathrm{pH})$, the maximum and minimum proportions of fungi found in the soil $\left(p_{\mathrm{f}, \max }\right.$ and $p_{\mathrm{f}, \min }$, respectively), and the $\mathrm{pH}$ at which the maximum and minimum proportions of soil fungi occur $\left(\mathrm{pH}_{\mathrm{f}, \max }\right.$ and $\mathrm{pH}_{\mathrm{f}, \min }$, respectively):

$$
p_{\mathrm{b}}=p_{\mathrm{f}, \text { max }}+\left(p_{\mathrm{f}, \text { min }}-p_{\mathrm{f}, \text { max }}\right)\left(\frac{\mathrm{pH}-\mathrm{pH}_{\mathrm{f}, \text { max }}}{\mathrm{pH}_{\mathrm{f}, \text { min }}-\mathrm{pH}_{\mathrm{f}, \text { max }}}\right)
$$

The proportion of fungi $\left(p_{\mathrm{f}}\right)$ is then calculated by the difference $\left(p_{\mathrm{f}}=1-p_{\mathrm{b}}\right)$. 
$\mathrm{C}$ and $\mathrm{N}$ may be returned to the soil by plant inputs, inorganic fertilizers, atmospheric deposition or organic amendments; they may then be lost from the soil by leaching, denitrification, volatilisation, crop offtake or through decomposition. In contrast to the complex layer structure used in SUNDIAL, in ECOSSE the soil is divided into equal $(5 \mathrm{~cm})$ layers for all processes throughout the soil profile, so as to facilitate the accurate simulation of processes to depth. As in SUNDIAL, leaching is simulated by simple piston (Saffigna \& Philips 2006) and bypass flow (Addiscott \& Whitmore 1991), but ECOSSE differs from SUNDIAL in that losses of dissolved organic C (DOC), and dissolved organic $\mathrm{N}$ (DON) are simulated as well as losses of nitrate $\left(\mathrm{NO}_{3}{ }^{-}-\mathrm{N}\right)$. Following an approach by Aguilar \& Thibodeaux (2005), the amount of DOC produced by a SOM pool is given by

$C_{\text {pool } \rightarrow \text { DOC }}=C_{\text {pool }} \exp \left(k_{\text {pool }} \times m^{\prime \prime}{ }_{\mathrm{w}} \times m^{\prime \prime}{ }_{\mathrm{t}} \times m^{\prime \prime}{ }_{\mathrm{C}} \times m_{\mathrm{pH}}\right)$

where $C_{\text {pool }}$ is the amount of $C$ in the DPM, RPM, BIO or HUM pools ( $\mathrm{kg} \mathrm{C} \mathrm{ha-1}$ ), $k_{\text {pool }}$ is the corresponding rate constant for production of DOC, and $m^{\prime \prime}{ }_{w}, m^{\prime \prime}$, $m^{\prime \prime}{ }_{\mathrm{c}}$ and $m^{\prime \prime}{ }_{\mathrm{pH}}$ are the rate modifiers for the water content, temperature, crop cover and $\mathrm{pH}$ of the soil, respectively, having the same form as the rate modifiers for aerobic decomposition. The amount of DON produced is calculated from the amount of DOC produced and the C:N ratio of the pool.

\subsection{Activity of soil organic matter decomposition}

Because the SOM pools have different rate constants, the relative proportions of these pools determines the activity of decomposition in the SOM as a whole; a greater proportion of a rapidly decomposing pool will result in greater overall activity of SOM decomposition, whereas a greater proportion of a slowly decomposing pool will result in lesser overall activity. Therefore, it is important to accurately determine the amount of $\mathrm{C}$ in each SOM pool at the start of the simulation. If plant inputs are well known and the soil has reached steady-state, the initial pool sizes can be determined directly from these specified inputs by running the model forward until the SOM content reaches steady-state. In practice, however, the actual plant inputs to a system are rarely known accurately, even at a field scale, because the full contribution of litter, debris and root exudates is difficult to measure. As the model is scaled up for national simulations, it becomes even more difficult to accurately estimate the organic inputs to a system.

Bradbury et al. (1993) resolved the problem of defining the initial activity of SOM decomposition using fixed proportions of the SOM pools dependent on the soil texture and dividing the measured soil $\mathrm{C}$ between the pools in these proportions. The proportions were based on observations from long-term experiments, but are highly site specific, so if long-term measurements are not available it can be difficult to establish the proportions needed for a particular soil type in a given environment. In ECOSSE, an iterative procedure is used to estimate the organic inputs and SOM pool sizes from

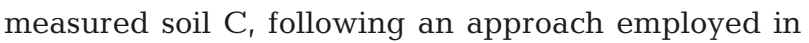
RothC, for example by Smith et al. (2005). An initial estimate of the total annual organic input is used to provide a first calculation of the $\mathrm{C}$ in each SOM pool at steady-state. Added together with the amount of material in the IOM pool, the $\mathrm{C}$ in these pools provides an estimate of the total soil $\mathrm{C}$ simulated using the given organic inputs. A rough estimate for the amount of material in the IOM pool is given by Falloon et al. (1998):

$$
\mathrm{C}_{\mathrm{IOM}}=0.049 \times \mathrm{C}_{\text {tot,meas }} 1.139
$$

where $\mathrm{C}_{\mathrm{IOM}}$ is the $\mathrm{C}$ in the IOM pool and $\mathrm{C}_{\text {tot,meas }}$ is the measured total soil $\mathrm{C}$, both given in $\mathrm{t} \mathrm{C} \mathrm{ha}^{-1}(25 \mathrm{~cm}$ layer $)^{-1}$. This equation was originally developed for a wide range of soils, but was mainly based on experiments on mineral soils. However, it provides sufficient accuracy in the estimate of the size of the IOM pool to be used to seed the iterative procedure. The model adjusts the annual organic inputs according to the ratio of simulated to measured soil C:

$$
\mathrm{C}_{\mathrm{in}}=\mathrm{C}_{\mathrm{in}, \mathrm{def}} \times \frac{\mathrm{C}_{\text {tot,meas }}-\mathrm{C}_{\mathrm{IOM}}}{\mathrm{C}_{\text {tot, } \mathrm{sim}}-\mathrm{C}_{\mathrm{IOM}}}
$$

where $C_{\text {in }}$ is the actual annual organic input, $C_{\text {in,def }}$ is the default annual organic input, $\mathrm{C}_{\text {tot,meas }}$ is the measured total soil $\mathrm{C}$ and $\mathrm{C}_{\text {tot,sim }}$ is the simulated total soil $\mathrm{C}$ (all kg C ha ${ }^{-1}$ layer $^{-1}$ ). Eq. (11) provides a revised estimate of the total annual organic inputs, which is then used to rerun the model to obtain a new simulation of the SOM pool sizes at steady-state. When the simulated and measured values are within $0.0001 \mathrm{~kg} \mathrm{C} \mathrm{ha}^{-1}$ layer $^{-1}$, the resulting SOM pool sizes and calculated organic inputs are used to represent the pools and inputs needed to achieve the observed soil C at steadystate. The model may then be run forward, applying changes in the soil conditions, land use and climate to calculate the impact of changes on the rate of SOM turnover.

In the calculations presented here, it was assumed that the soils were in equilibrium, and so were neither losing nor gaining soil C. If it had been known that the soil was not in equilibrium, ECOSSE has been developed so that the initialization could be run to match the annual change in soil $\mathrm{C}$ known to be occurring at the site (Smith et al. 2010). However, because this informa- 
tion was not available at the national scale, the assumption of a soil at equilibrium was used. Running the model in this way will result in an overestimate of soil $\mathrm{C}$ losses in a soil that is actually gaining soil $\mathrm{C}$, and an underestimate of soil $\mathrm{C}$ losses in a soil that is actually losing soil $\mathrm{C}$. However, the error in the change in soil $\mathrm{C}$ losses associated with a given change in land use will be small.

This iterative procedure is a useful approach, especially in national simulations, as it provides an estimate of the rate of decomposition using very little input data. Any factors that are not explicitly described in the measurements used to drive the model will be subsumed into the description of the rate of decomposition provided by the relative pool sizes. For instance, if the soil is saturated for much of the year, this is reflected in a slower rate of decomposition, resulting in a higher observed total soil $\mathrm{C}$, which then requires a larger component of the SOM to be composed of the more slowly decomposing HUM pool. If the saturated condition of the soil had been explicitly included in the measurements used to drive the model, the slowed rate of decomposition would instead have been described by a slowed decomposition rate simulated under the entered anaerobic conditions. This would have provided a more accurate simulation of the impact of any factors that might change the water table depth, such as changes in rainfall patterns. If the simulations are focusing on the impact of changes in climate on SOM turnover in soils that are likely to become saturated, it is important that the water table depth be included as an input driver, but if the soils are not likely to become saturated, this is less important. The user should be aware of any limitations in the results introduced by using less data to drive the model, but the ability to run simulations in this way - using only the data that are readily available - is a major advantage of the ECOSSE approach, especially for large-scale simulations such as those at a national scale.

\subsection{Land-use change}

The changes imposed in the ECOSSE simulations when one land use is converted to another are: (1) a change in the DPM:RPM ratio of the plant inputs, (2) a change in the plant inputs of the established vegetation, (3) a temporary reduction in the plant inputs from that of established vegetation until the vegetation becomes fully established, and (4) a release on cultivation of physically protected SOM from the HUM pool, partitioned into the DPM and RPM pools in the DPM:RPM ratio of the original land use. The implementation of these changes depends on the type of land-use change (Table 3).
Table 3. Imposed changes in the ECOSSE simulations when one land use is changed to another. (1) Change in the DPM:RPM ratio of the plant inputs; (2) change in the plant inputs of the established vegetation; (3) temporary reduction in the plant inputs from that of established vegetation until the vegetation becomes fully established; (4) release on cultivation of physically protected SOM from the HUM pool, partitioned into the DPM and RPM pools in the ratio of the DPM:RPM in the original land use. See Tables $1 \& 2$ for definitions of abbreviations

\begin{tabular}{|lcccc|}
\hline \multirow{2}{*}{ Land use 1 } & \multicolumn{4}{c|}{ Land use 2 } \\
\cline { 2 - 5 } & Arable & Grassland & Forestry & $\begin{array}{c}\text { Semi- } \\
\text { natural }\end{array}$ \\
\hline Arable & & 2 & $1,2,3$ & $1,2,3$ \\
Grassland & 2,4 & & $1,2,3,4$ & $1,2,3,4$ \\
Forestry & $1,2,4$ & $1,2,4$ & & $1,2,3,4$ \\
Semi-natural & $1,2,4$ & $1,2,4$ & $1,2,3,4$ & \\
\hline
\end{tabular}

\subsubsection{Change in the DPM:RPM ratio of the plant inputs}

In both the RothC and ECOSSE models, the activity of decomposition of the organic matter added to the soil is described by the DPM:RPM ratio. This can be specified for each individual crop type or for broader categories of vegetation based on land-use type. In these simulations, the DPM:RPM ratio is set for the land use categories arable, grassland, forestry and semi-natural: the value for arable and grassland is 1.44 , for forestry 0.25 and for semi-natural land 0.67 , as given by Coleman \& Jenkinson (1996). The DPM:RPM ratio of plant inputs changes on conversion between all land-use categories except for the conversion of arable to grassland or grassland to arable.

\subsubsection{Change in the plant inputs of the established vegetation}

The plant inputs of the established vegetation for the different land-use types are calculated during an iterative initialization procedure as described in Section 2.4. On conversion of land use, the plant inputs are changed from the amount calculated for the first land use to the amount calculated for the new land use.

\subsubsection{Temporary reduction in the plant inputs from that of established vegetation}

In an analysis of $\mathrm{CO}_{2}$ flux measurements from Scottish peatlands that were drained, ploughed and afforested with conifer plantation dominated by Sitka spruce Picea sitchensis, Hargreaves et al. (2003) ob- 
served changes in soil C associated with reduced plant inputs when vegetation is immature. An initial loss of $\mathrm{C}$ due to soil disturbance was observed up to $5 \mathrm{yr}$ after afforestation, followed by a period up to $10 \mathrm{yr}$ where C sequestration from ground vegetation countered emissions from soil disturbance, resulting in net sequestration. After 15 yr, Hargreaves et al. (2003) observed that canopy closure resulted in less ground vegetation and the peat became an increasing source of $\mathrm{C}\left(\sim 1 \mathrm{t} \mathrm{C} \mathrm{ha}{ }^{-1}\right.$ $\left.\mathrm{yr}^{-1}\right)$. The reduced plant inputs when vegetation is immature are described in ECOSSE by reducing the plant inputs from established vegetation by a fixed proportion for each land-use type and allowing it to return to the steady-state level over a number of years following a linear response. For conversion to arable and grassland there is no reduction in plant inputs; for forestry, the plant inputs are reduced in the year of planting to $50 \%$ of the plant inputs calculated for mature vegetation; for semi-natural vegetation, plant inputs are reduced to zero (Smith et al. 2010). The plant inputs are assumed to recover to the steady state after $5 \mathrm{yr}$ in forestry and $20 \mathrm{yr}$ in semi-natural vegetation. These reduction rates and times were set to emulate the observations of Hargreaves et al. (2003) and Ejrnæs et al. (2008). This is a necessarily simplistic approach, accounting for the detailed interactions of inputs from the understory vegetation, canopy closure and maturity using just one simple equation. For national-scale simulations it provides an appropriate detail of output given the accuracy of input data possible (Smith et al. 2010). The impact of different management options, or species characteristics on recovery of plant inputs, can be described by adjusting the parameters describing reduction in plant inputs and the time required to reach maturity according to experimental evidence.

\subsubsection{Release on cultivation of physically protected SOM}

When one land-use type is converted to another, the observed changes in soil C can only partly be attributed to the change in plant inputs from the different vegetation types. In a meta-analysis of 74 publications, including data from 16 different countries on the impact of land-use change on soil C stock, Guo \& Gifford (2002) found an initial reduction in soil C when pasture was converted to plantation, despite a greater input from the plantation vegetation. This is consistent with the decline in total soil $\mathrm{C}$ observed by Zerva et al. (2005) during the first rotation following afforestation of a peaty gley soil in NE England. The extent of the decline in soil $\mathrm{C}$ content is highly dependent on soil type, the management of the land and the nature of disturbance of the soil. Guo \& Gifford (2002) attributed the decline in soil $\mathrm{C}$ content on land-use change from grassland to forestry to (1) the shallower distribution of soil $\mathrm{C}$ in afforested soils as compared to grassland soils, resulting in less $\mathrm{C}$ in the soil profile as a whole despite a greater surface soil $\mathrm{C}$ stock under trees; (2) the persistent tree root system, resulting in the annual turnover of organic matter from dying tree roots being less than from dying grass roots; and (3) woody plants depositing a larger fraction of organic matter on the surface than grasses, resulting in less formation of stabilized SOM. In organic soils, these effects may be accentuated by site drainage during site preparation for afforestation (Freeman et al. 1993, Reynolds 2007). Gottschalk et al. (2009) attributed the decline in soil $\mathrm{C}$ observed with the conversion of forestry to arable land to the loss of physically protected soil $\mathrm{C}$, as well as to reduced plant inputs and increased erosion from arable land. Using ${ }^{13} \mathrm{C}$ measurements, Gottschalk et al. (2009) showed that RothC did not capture the observed rapid decline in forestderived soil $\mathrm{C}$ on deforestation, and suggested the model needed to account for the release of physically protected soil C on disturbance of long-term uncultivated soil. In ECOSSE, the reduction in the physical protection of SOM is described by a simple approach in which a proportion of the slowly decomposing HUM pool is passed back to the more rapidly turning over DPM and RPM pools. Therefore, the SOM that was previously slowly decomposing in the HUM pool will decompose more rapidly, thus releasing $\mathrm{CO}_{2}$ more quickly, as would occur with the loss of physical protection on cultivation. The proportion of the HUM pool that is passed back to DPM and RPM pools represents the plant material that has become resistant to decomposition through physical protection within soil aggregates, and thus the loss of physical protection on aeration of the soil and breakdown of the soil aggregates. The proportion passed back from the HUM pool for land uses that are not cultivated annually (grassland, forestry and semi-natural) is currently set to 0.5 , following an analysis by West \& Post (2002) of global data on the effects of tillage on losses of $\mathrm{C}$ from the soil. For arable land, the proportion is set to zero, as soil is usually cultivated annually as part of conventional cropland management. If cropland management options such as zero tillage had been used, the proportion of HUM passed to the more rapidly decomposing pools should be increased according to any experimental evidence on the impact of zero tillage on soil C stocks. Similarly, if management options have been used that result in minimal soil disturbance during land-use change on long-term uncultivated soils, the proportion of HUM passed should be reduced from 0.5 . 


\section{UNCERTAINTY IN NATIONAL SIMULATIONS}

\subsection{Sources of uncertainty}

Uncertainty in national-scale simulations has 2 components: uncertainty due to errors in the model, and uncertainty due to the reduced detail and precision in the data available. Field-scale evaluations of the uncertainty due to errors in the model, referred to by Beven (2002) as structural errors, are described elsewhere (Smith et al. 2010) and are not included here. When the model is applied at the national scale, the uncertainty in simulations is likely to be greater than at the field scale due to the reduced detail of the inputs. For example, in croplands, detailed management factors such as sowing date and timing of fertilizer applications cannot usually be specified when the resolution of the simulations is larger than the size of the management unit; the resolution of the simulation might be a $1 \mathrm{~km}^{2}$ grid cell, whereas the size of a management unit might be a 5 ha field, so there will be many different values for the management factors within each $1 \mathrm{~km}^{2}$ cell. Uncertainty in simulations at the national scale is also greater than at the field scale due to the reduced precision of the input values. For example, the $\mathrm{C}$ content of the soil in a 10 ha field can be precisely measured, and the error in the measurement defined using replicates, whereas for applications at the national scale the soil $\mathrm{C}$ content is often determined for $1 \mathrm{~km}^{2}$ grid cells with the $\mathrm{C}$ content estimated from typical or average soil $\mathrm{C}$ values for the major soil types identified in the cell (e.g. Batjes 2009).

The uncertainty due to simulation errors and the measurement errors associated with the reduced detail and precision of data available to run the model at national scale can be quantified by evaluating the model at the field scale, but using only input drivers that are available at the national scale. In order to obtain a good representation of the uncertainty, a range of sites across the whole area to be simulated should be included in this field-scale evaluation. Here we use data from the National Soil Inventory of Scotland (NSIS; Lilly et al. 2009) to determine the uncertainty in national-scale simulations of changes in the soil C stocks of Scotland.

\subsection{Use of measurements from the NSIS}

The full NSIS data set comprises a point database, collected on a $5 \mathrm{~km}$ grid across Scotland (Lilly et al. 2009). The inventory was undertaken between 1978 and 1988, and the site conditions and soil profiles were characterized at the 3094 locations having soil cover (soil samples could not be obtained at some locations, for example, where the location was built up or on water). A subset of soils at locations on a $10 \mathrm{~km}$ grid (721 grid points) was sampled by pedological horizons using standard procedures and protocols. The soil was subsequently analyzed to determine soil chemical and physical characteristics. Between 2007 and 2009, a statistically unbiased subset of the original 721 locations was re-sampled and additional measurements were made at each location that had soil cover (183 sites) to allow the soil $\mathrm{C}$ stock to be estimated and provide an estimate of the uncertainty. In both campaigns, soils were mainly sampled to a maximum depth of $1 \mathrm{~m}$, and so the data set excludes soil $\mathrm{C}$ held in deeper peat layers, but allows direct comparison of the changes in soil $\mathrm{C}$ held in the top $1 \mathrm{~m}$ of soil between the 1980s and the present day. Note that limiting measurements to $1 \mathrm{~m}$ depth could introduce errors if the bulk density of the soil has increased significantly, resulting in a larger proportion of the soil profile being sampled (Ellert et al. 1995). Ideally, the bulk density values should have been checked for any significant changes, but this could not be done as the earlier campaign did not include bulk density measurements.

Here we only use data for 60 of the NSIS sites, i.e. those sampled in 2007 and where analyses had been completed at the time of the present study. The subset of re-sampled sites encompasses the range of organic, organo-mineral and mineral soils found across Scotland. The ECOSSE model was run using real weather data and only the limited soil, land-use and management data that would be available in the large-scale national simulations. Therefore, by comparing the simulated values with the measurements of soil $\mathrm{C}$ at the re-sampling date, these simulations provide a test of the accuracy of changes in soil $\mathrm{C}$ due to climate and land-use change obtained in national simulations of Scotland.

\subsection{Calculating uncertainty}

Good model performance is indicated statistically by simulations and measurements that are both coincident (indicating a close fit) and associated (indicating the trends in measurements are replicated) (Smith \& Smith 2007). Where measurements are replicated, the coincidence between simulated and measured values is best expressed as the lack-of-fit statistic, and the significance of the coincidence determined using an F-test (Whitmore 1991). However, the NSIS data set is not replicated, so instead the degree of coincidence was determined by calculating the total error as the root mean squared error (RMSE) and the bias in the error as the relative error (Loague \& Green 1991, Smith et al. 1996b, 1997). The association between simulated 
and measured values was calculated as the correlation coefficient, and the significance of the correlation was determined using a $t$-test (Smith \& Smith 2007). Sources of model error were also examined using graphical plots.

\subsection{Input data}

The input data were limited to those available at the national scale, so that the simulations provide an estimate of the uncertainty when the model is run using national databases to estimate changes in soil C stock for all of Scotland. This result can then be used in assessing the uncertainty associated with lack of detail and precision in data available in the national-scale simulations.

The characteristics of each horizon in the soil series identified at the NSIS site were used to drive the model in each layer down the soil profile. Total soil C ( $\mathrm{kg} \mathrm{C}$ $\mathrm{ha}^{-1}$ ) was used to determine the organic inputs to the soil and the amount of $\mathrm{C}$ in each of the SOM pools at the start of the simulation as described in Section 2.4. These total soil $\mathrm{C}$ values were calculated from the measured percentage soil $C$ in each horizon and the bulk density. Soil bulk density $\left(d_{\mathrm{b}}\right)$ was derived using the following equations developed from data held in the Scottish Soils Database:

If percent carbon in the soil layer $\left(P_{\mathrm{C}}\right)$ is $>22 \%$, then:

$$
d_{\mathrm{b}}=1.772-0.413 \ln P_{\mathrm{C}}
$$

If $P_{\mathrm{C}}$ is $\leq 22 \%$, then:

$$
d_{\mathrm{b}}=1.536-0.0472 \times P_{\mathrm{C}}
$$

This was done for the original land use observed in the 1978-1988 sampling as well as for any new land use observed in the 2007-2009 sampling, thus allowing the impact of land-use change on SOM turnover to be simulated. Soil $\mathrm{pH}$ was used to calculate rate-modifying factors for aerobic and anaerobic decomposition as shown in Eqs. (3) and (6), and to determine the stable C:N ratio given in Eq. (8). The percentage clay $\left(P_{\mathrm{K}}\right)$ was used to calculate the proportion of SOM retained in the soil on decomposition following the approach of Coleman \& Jenkinson (1996) and, together with the

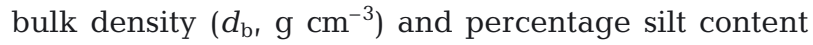
$\left(P_{\mathrm{s}}\right)$, to estimate the water content between field capacity and permanent wilting point $\left(\theta_{\mathrm{f}}\right)$, using the following equation adapted from Hall et al. (1977):

$$
\begin{aligned}
\theta_{\mathrm{f}}= & \left(47+0.25 K+0.1 P_{\mathrm{s}+} \frac{1.12 \mathrm{C}_{\mathrm{tot}, \mathrm{sim}}}{d_{\mathrm{b}} \times 10^{6}}-\right. \\
& \left.16.52 d_{\mathrm{b}}-\left(2.94+0.83 P_{\mathrm{K}}-0.0054 P_{\mathrm{K}}^{2}\right)\right)
\end{aligned}
$$

Eq. (14) was originally derived to determine field capacity in soils from England and Wales, and so will introduce some error when applied to Scottish soils, especially peats. However, because the activity of SOM decomposition is initialized using the specified soil conditions as described in Section 2.4, the impact on changes in soil $\mathrm{C}$ of errors in estimated field capacity will be small. This was demonstrated by rerunning the model using alternative pedotransfer functions derived for organic soils in the UK as part of an update to the SEISMIC environmental information and scenario mapping system (http://randd.defra.gov.uk/ Document.aspx?Document=PS2225_7916_FRP.pdf).

The most suitable equation for Scottish peat soils was:

$$
\theta_{\mathrm{f}}=65.1+\left(0.348 \times P_{\mathrm{C}}\right)-\left(30.751 \times d_{\mathrm{b}}\right)
$$

The difference in the change in soil $\mathrm{C}$ was less than $0.01 \%$ of the total $\mathrm{C}$ change. If the focus of the simulations was the impact of changes in the soil water status on soil $\mathrm{C}$, a more specific pedotransfer function might be required.

The water content and temperature rate modifiers given in Eqs. (1, 4 \& 5) were calculated using weather data, downloaded as a grid of $5 \mathrm{~km}^{2}$ cells from the climate monitoring service of the MetOffice UK. These data were also used to simulate leaching, denitrification and volatilization as described by Bradbury et al. (1993). Long-term average monthly data based on the period of 1961-1990 were used in the calculation of the amount of $\mathrm{C}$ in the SOM pools at the start of the simulation and the organic inputs for each land-use type. Actual monthly data were used to run the model forward to simulate any impacts of climate change between the 2 sampling times.

Rock, iron pans and other layers with slow permeability to water were assumed to be the bottom of the profile for the purpose of simulation modelling. Soil C measurements for the top litter layers were frequently missing, and so the simulations could not be evaluated in these litter layers. The national simulations included all layers in the soil profile; this often includes litter layers. If the uncertainty in the simulation of litter layers is very different to that of other layers, this could introduce an error in the estimate of uncertainty in the national simulations; additional data are required to resolve this issue.

Total C was calculated for each depth using bulk density and percent soil $\mathrm{C}$. The amount of $\mathrm{C}$ was corrected for the percentage of stones in the soil. In some instances, the percentage of stones changed between the 2 sampling times. This is likely to be due to spatial variability at the site. To allow comparison between the soil $\mathrm{C}$ contents at the 2 sampling times, the $\mathrm{C}$ content of the soil at the second sampling time was adjusted assuming the percentage of stones to be equivalent to the percentage found at the first sampling time. Horizon depths were corrected similarly. 


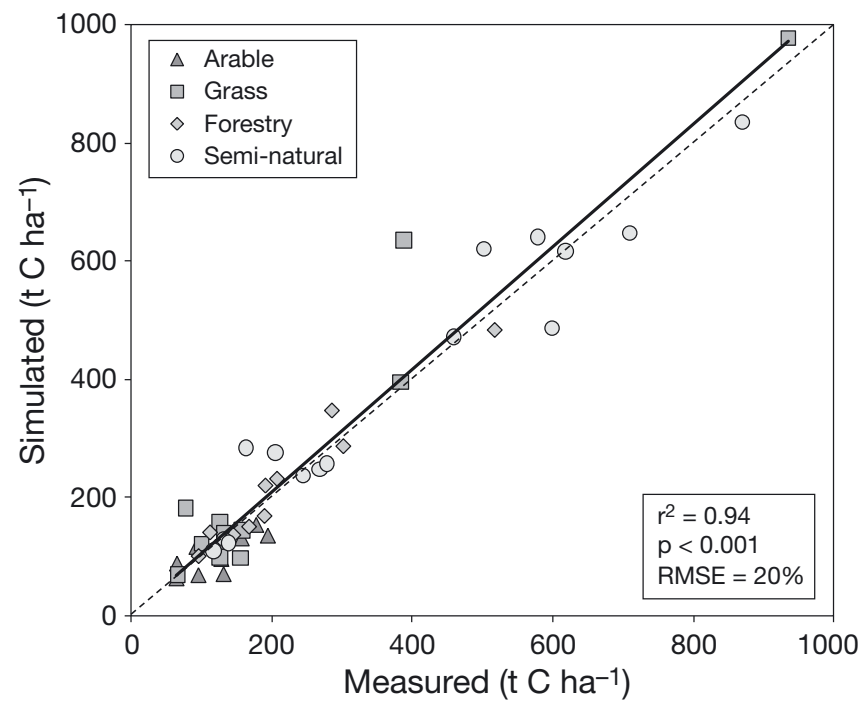

Fig. 2. Simulated versus measured values of soil organic carbon in the $0-100 \mathrm{~cm}$ soil profile at the 2007 sampling. RSMSE: root mean squared error

\subsection{Results of simulations of changes in soil $\mathrm{C}$ in the NSIS}

We plotted the simulated soil $\mathrm{C}$ against the measured data at 60 resampled sites (Fig. 2). The 1:1 line is given in the plot, and represents perfect agreement between the simulations and the measurements. The spread of points around the 1:1 line indicates that there are some errors in the simulation of changes in soil $\mathrm{C}$ with time since the first sampling date. However, over all sites, the correlation between the simulated and measured values is high and statistically significant $\left(\mathrm{r}^{2}=0.94, \mathrm{p}<0.001\right)$ for all land uses (Table 4$)$.

Overall, the total error (RMSE) between the simulated and measured values of $C$ is $20 \%$ of the average measurement. Larger errors between simulations and measurements occur at some sites. As discussed below, these are associated with inaccuracies in the measurement inputs, as well as being due to the model. However, because these errors are part of the uncertainties

Table 4. Evaluation of the degree of association and coincidence between values simulated by ECOSSE using the limited data input available at a national scale and measurements at the 62 NSIS sites. RMSE: root mean squared error

\begin{tabular}{|lcrc|}
\hline Land use & \multicolumn{2}{c|}{$\begin{array}{c}\text { Association } \\
\text { r }\end{array}$} & \multicolumn{2}{c|}{$\begin{array}{c}\text { Lack of coincidence } \\
\text { RMSE (\%) }\end{array}$} \\
\hline Arable & 0.91 & $<0.001$ & 21 \\
Grassland & 0.93 & $<0.001$ & 39 \\
Forestry & 0.97 & $<0.001$ & 19 \\
Semi-natural & 0.94 & $<0.001$ & 15 \\
Overall land uses & 0.94 & $<0.001$ & 20 \\
\hline
\end{tabular}

encountered in the simulations at a national scale, these values should be included in the potential uncertainty in the simulations.

The simulated change in $\mathrm{C}$ content was compared to the measured $\mathrm{C}$ change. This is expressed as a percentage change to normalise the impact of $C$ change at sites with large and small C content (Smith et al. 1996b). Unfortunately, the errors in the measurements with this type of re-sampling exercise can be extremely high. This is due to the inherent spatial variability, especially at unmanaged sites, as well as any unrecorded management between the first and second sampling dates and the difficulty in relocating sampling sites (Lilly et al. 2009). At sites where no land-use change has occurred, the uncertainties in the measurements are larger than the simulated change in soil $C_{\text {, }}$ and so no meaningful statistical analysis was possible. Simulated change in soil $\mathrm{C}$ at the sites where land-use change has occurred is shown in Fig. 3. Only these latter sites are included in the following analysis.

Simulation of change in $\mathrm{C}$ content is a more stringent test of the model than the simulation of total $\mathrm{C}$ content. Over all sites where land-use change has occurred, the correlation between the simulated and the measured values is given by $\mathrm{r}^{2}=0.25$. This is not significant, suggesting the simulations and measurements are not highly associated. However, this changes when the experimental error is taken into account. For 4 sites, the $95 \%$ confidence intervals of the measurements are very high, $>35 \%$ (Table 5). If these sites are excluded from the analysis, the correlation coefficient increases to 0.80 . Although the $r^{2}$-value is high, this is still not

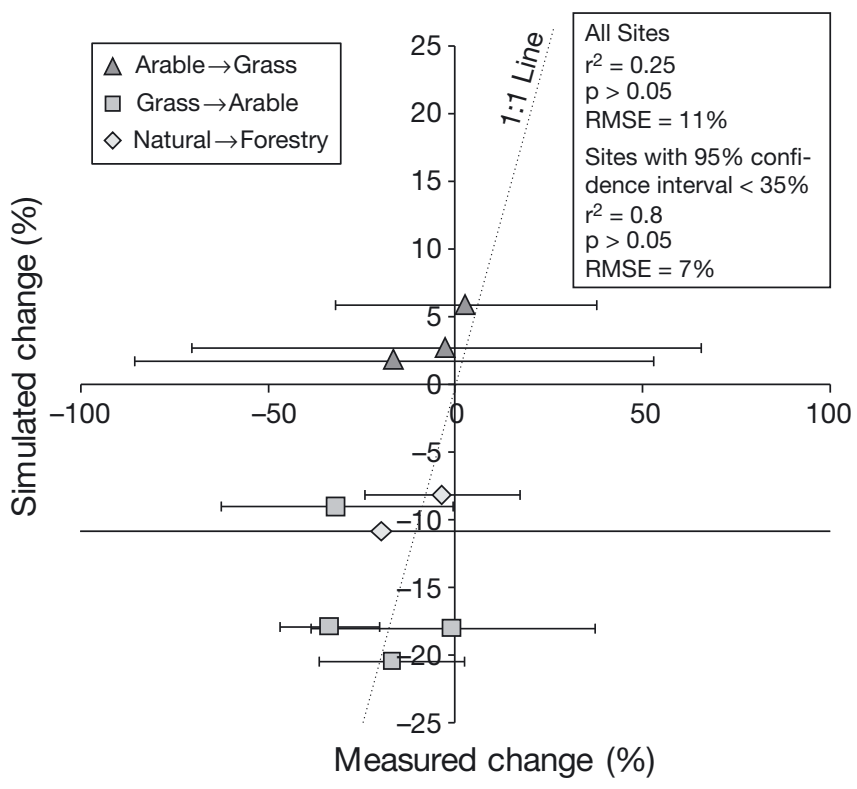

Fig. 3. ECOSSE-simulated values against measured values of change in carbon content for the 9 NSIS sites where land-use change has occurred. Error bars are $95 \%$ confidence intervals 
Table 5. Estimated errors in measurement at the 9 NSIS sites where land-use change occurs. $95 \%$ CI: $95 \%$ CI in measurement of \% change in soil C

\begin{tabular}{|c|c|c|}
\hline $\begin{array}{l}\text { Land-use } \\
\text { change }\end{array}$ & Soil association/Series/Type & $95 \% \mathrm{CI}$ \\
\hline $\begin{array}{l}\text { Arable to } \\
\text { grassland }\end{array}$ & $\begin{array}{l}\text { Alluvial/Traquair } \\
\text { Alluvial/Lochside } \\
\text { Balrownie/Balrownie/Brown } \\
\text { earth with gleying }\end{array}$ & $\begin{array}{l}68 \\
35 \\
69\end{array}$ \\
\hline $\begin{array}{l}\text { Grassland to } \\
\text { arable }\end{array}$ & $\begin{array}{l}\text { Tynet/Aulthash/Humus iron podzol } \\
\text { Tarves/Thistlyhill/Brown earth } \\
\text { with gleying } \\
\text { North Mormond/North Mormond/ } \\
\text { Brown earth with gleying } \\
\text { Auchenblae/Auchenblae/ } \\
\text { Humus iron podzol }\end{array}$ & $\begin{array}{l}19 \\
38 \\
13 \\
31\end{array}$ \\
\hline $\begin{array}{l}\text { Semi-natural } \\
\text { to forestry }\end{array}$ & $\begin{array}{l}\text { Arkaig/Kildonan/Peaty podzol } \\
\text { Strichen/Strichen/Humus iron } \\
\text { podzol and iron podzol }\end{array}$ & $\begin{array}{c}21 \\
180\end{array}$ \\
\hline $\begin{array}{l}\text { Average } \\
\text { Average excluding } \\
\text { sites with } 95 \% \text { CI > 35\% }\end{array}$ & & $\begin{array}{l}53 \\
24\end{array}$ \\
\hline
\end{tabular}

significant, due to the low number of measurements now included in the comparison (only 5). However, the simulated values are all within the measured $95 \%$ confidence interval of the 1:1 line between simulations and measurements, suggesting the association between simulations and measurements is within the range of experimental error.

The average deviation between the simulations and the measurements is only $11 \%$ if all points are included, and $7 \%$ if the measurements with high experimental error are excluded. This is less than the average measured deviation at the $95 \%$ confidence interval (53\% for all points and $24 \%$ when measurements with high experimental errors are excluded, see Table 5). Therefore, the coincidence between the simulations and the measurements is also well within the range of experimental error; the model cannot be improved further against this data (Smith \& Smith 2007). The bias in the simulations, as indicated by the relative error (Loague \& Green 1991, Smith et al. 1996b, 1997), is very low: $-4 \%$ for all measurements. Therefore, only a small systematic underestimate $(-4 \%)$ is expected in the national simulations.

The simulations at the sites where land-use change has occurred are all within the range of experimental error, but at $25 \%$ of the sites without land-use change ( $22 \%$ of all sites) the simulated values show a greater deviation from the measurement than the recorded experimental error. The sites where the error between simulations and measurements exceeds the recorded experimental error include all land-use types, so no systematic error due to including a particular land-use type has been identified. At 2 arable sites, ECOSSE simulates a small decline in soil C (-2 and $-6 \%)$, whereas a large increase is measured (+33 and $+79 \%$ respectively). It is unlikely that such a large increase in soil $\mathrm{C}$ would occur without some change in land use or management, but there is no record of any such changes. This illustrates one type of error that occurs, not due to the failure of the model, but rather due to the limited data available for national-scale simulations. These errors may have been attributable to the use of improved crop varieties, changes in cropping practice (such as straw incorporation) or the inclusion of a short-term ley within the arable rotation resulting in a temporary increase in soil $\mathrm{C}$ before the land is used for crop production again. Similarly, at 2 grassland and 2 semi-natural sites, a relatively large decline in soil $\mathrm{C}$ is measured (grass $=-19$ and $-4 \%$; semi-natural $=-43$ and $-16 \%)$, whereas the model simulates a small increase (grass $=+2$ and $+3 \%$; semi-natural $=+2$ and $+4 \%$ ). This again could be due to an interim period of land-use change, resulting in the reduction in soil $\mathrm{C}$, before the land is converted back to grassland or semi-natural use. At one forestry site, a moderate decline in soil $\mathrm{C}$ is observed $(-12 \%)$, whereas an increase is simulated $(+3 \%)$. This may be attributable to disease, drainage of a highly organic site or inaccurate assumptions about the age class of the forestry. At the remaining 44 sites, the simulated values have the same sign as the measurements, and are usually within or only slightly outside the reported experimental error.

\section{IMPLICATIONS FOR NATIONAL SIMULATIONS}

The ECOSSE approach assumes similar processes can occur in mineral and organic soils, but the extent of the processes is modified by the soil conditions. This combined approach is in contrast to previous work, where mineral and organic soils have been treated differently, assuming that many of the processes occurring in mineral and organic soils are fundamentally different (e.g. Bradbury et al. 1993, Clymo 1992). This ability to use a combined approach is an important assumption for application of the model at national scale, as it avoids the need for an arbitrary differentiation between soils that are considered to be organic and those that are assumed to function as mineral soils, and allows the whole area to be simulated using the same model.

Because ECOSSE is able to function at field as well as national scales, if appropriate input data are used, 
field-scale evaluations can be used to determine uncertainty in national simulations. However, despite using a large survey of soils data in Scotland (Lilly et al. 2009), the evaluations were limited to only a few sites. This was due to the large uncertainty inherent in such measurements compared to the size of the changes in soil C observed; only at sites where land use had changed was the change in soil $\mathrm{C}$ significant. Therefore, only these sites could be included in the statistical analysis. Much of this measurement error is introduced by semi-natural upland sites; the inherent measurement error is greater in semi-natural upland sites where variations in vegetation and topography introduce greater spatial variation in soil characteristics than in arable or grassland sites (Lindsay et al. 1985). Improved estimates of uncertainty could be achieved by separating out analyses for semi-natural uplands and focusing research effort on improving measurements at these sites.

Uncertainty in the simulations is also introduced by uncertainties in the input data, including uncertainties in timing of land-use change, actual management of arable land, grassland and forestry, and unrecorded land-use change before the start of and during the simulation. These factors are also likely to be unknown at a national scale, and so the erroneous results due to uncertainty in the input data are included in the estimate of uncertainty in the simulations. For a further discussion of uncertainty estimates, see Falloon et al. (2006).

Despite the uncertainties in the input data and the measurements used to evaluate the model, the simulated values show a high degree of association with the measurements in both total $\mathrm{C}$ and change in $\mathrm{C}$ content of the soil. Over all sites where land-use change occurred, the average deviation between the simulated and measured values of percentage change in soil C was less than the experimental error (11\% simulation error, 53\% measurement error). This suggests that the uncertainty in using this model for the national-scale simulations will be $\sim 11 \%$. Note that this excludes any additional uncertainty due to uncertainty in the national database values used to drive the model. Only a small bias in the simulations was observed compared to the measured values, suggesting that a small underestimate of the change in soil $\mathrm{C}$ should be expected at a national scale $(-4 \%)$.

Acknowledgements. This work was funded by the Rural and Environment Research and Analysis Directorate of the Scottish Government, Science Policy and Co-ordination Division, and the Welsh Assembly Government. P.S. is a Royal SocietyWolfson Research Merit Award holder. Rothamsted Research is an institute of the Biological and Biological Sciences Research Council. A.W. and K.C. acknowledge support from the Institute Strategic Programme Grants on Bioenergy and
Climate Change and the Cross Institute Programme on Sustainable Soil function (SoilCIP). P.F. was supported by the Joint DECC and Defra Integrated Climate Programme (DECC/Defra GA01101), and the EU Sixth Framework Programme (Global Change and Ecosystems sub-programme) project CarboNorth (project no. 036993).

\section{LITERATURE CITED}

Addiscott TM, Whitmore AP (1991) Simulation of solute leaching in soils of differing permeabilities. Soil Use Manag 7:94-102

Aguilar L, Thibodeaux LJ (2005) Kinetics of peat soil dissolved organic carbon release from bed sediment to water. I. Laboratory simulation. Chemosphere 58:1309-1318

Bardgett RD, McAlister E (1999) The measurement of soil fungal: bacterial biomass ratios as an indicator of ecosystem self-regulation in temperate meadow grasslands. Biol Fertil Soils 29:282-290

Batjes NH (2009) Harmonized soil profile data for applications at global and continental scales: updates to the WISE database. Soil Use Manag 25:124-127

Beven K (2002) Towards a coherent philosophy for modelling the environment. Proc R Soc Lond A 458:2465-2484.

Bradbury NJ, Whitmore AP, Hart PBS, Jenkinson DS (1993) Modelling the fate of nitrogen in crop and soil in the years following application of ${ }^{15} \mathrm{~N}$-labelled fertilizer to winter wheat. J Agric Sci 121:363-379

Clymo RS (1992) Models of peat growth. Suo 43:127-136

Coleman K, Jenkinson DS (1996) RothC-26.3. A model for the turnover of carbon in soil. In: Powlson DS, Smith P, Smith JU (eds) Evaluation of soil organic matter models using existing long-term datasets. NATO ASI Series I, Vol 38. Springer, Berlin, p 237-246

> Ejrnæs R, Liira J, Poulsen RS, Nygaard B (2008) When has an abandoned field become a semi-natural grassland or heathland? Environ Manag 42:707-716

Ellert BH, Janzen HH, McConkey BG (1995) Measuring and comparing soil carbon storage. In: Lal R, Kimble JM, Follet $\mathrm{RF}$, Stewart BA (eds) Assessment methods for soil carbon. Lewis Publishers, Boca Raton, FL, p 131-146

Falloon P, Smith P, Coleman K, Marshall S (1998) Estimating the size of the inert organic matter pool for use in the Rothamsted carbon model. Soil Biol Biochem 30:1207-1211

Falloon P, Smith P, Bradley RI, Milne R and others (2006) RothCUK - a dynamic modelling system for estimating changes in soil $\mathrm{C}$ at $1-\mathrm{km}$ scale in the UK. Soil Use Manag 22:274-288

> Freeman C, Lock MA, Reynolds B (1993) Fluxes of $\mathrm{CO}_{2}, \mathrm{CH}_{4}$ and $\mathrm{N}_{2} \mathrm{O}$ from a Welsh peatland following simulation of water table draw-down: potential feedback to climatic change. Biogeochemistry 19:51-60

> Garcia JL, Patel BKC, Ollivier B (2000) Taxonomic, phylogenetic, and ecological diversity of methanogenic Archae. Anaerobe 6:205-226

> Gorham E (1991) Northern peatlands: role in the carbon budget and probable responses to global warming. Ecol Appl 1:182-195

Gottschalk P, Bellarby J, Chenu C, Foereid B and others (2009) Simulation of soil organic carbon response at forest cultivation sequences using ${ }^{13} \mathrm{C}$ measurements. Org Geochem 41:41-54

> Guo LB, Gifford RM (2002) Soil carbon stocks and land use change: a meta analysis. Glob Change Biol 8:345-360

Hall DG, Reeve MJ, Thomasson AJ, Wright VF (1977) Water retention, porosity and density of field soils. Technical 
Monograph No. 9. Soil Survey of England and Wales, Harpenden, p 32-42

Hargreaves KJ, Milne R, Cannell MGR (2003) Carbon balance of afforested peatland in Scotland. Forestry 76: 299-317

IPCC (2007) Climate change 2007: the physical science basis. In: Solomon S, Qin D, Manning M, Chen Z and others (Eds) Contribution of Working Group I to the Fourth Assessment Report of the Intergovernmental Panel on Climate Change. Cambridge University Press, Cambridge

Jenkinson DS, Rayner JH (1977) The turnover of organic matter in some of the Rothamsted classical experiments. Soil Sci 123:298-305

Jenkinson DS, Hart PBS, Rayner JH, Parry LC (1987) Modelling the turnover of organic matter in long-term experiments at Rothamsted. INTECOL Bull 15:1-8

Joosten H (2009) The IMCG global peatland database. International Mire Conservation Group, available at www. imcg.net/gpd/gpd.htm

Kettunen A (2003) Connecting methane fluxes to vegetation cover and water table fluctuations at microsite level: a modelling study. Global Biogeochem Cycles 17:1051 doi: 10.1029/2002BG001958

Lal R (2004) Soil carbon sequestration impacts on global climate change and food security. Science 304:1623-1627

Leifeld J, Zimmermann M, Fuhre J (2008) Simulating decomposition of labile soil organic carbon: effects of $\mathrm{pH}$. Soil Biol Biochem 40:2948-2951

Lilly A, Towers W, Malcolm A, Paterson E (2004) Report on a workshop on the development of a Scottish Soils Knowledge and Information Base (SSKIB). Proceedings of a Workshop, Macaulay Institute, 22 Sep 2004. Macaulay Land Use Research Institute, Aberdeen, available at www.macaulay.ac. uk/workshop/SSKIB/SSKIBWorkshop_Report.pdf

Lilly A, Bell JS, Hudson G, Nolan AJ, Towers W (2009) National Soil Inventory of Scotland 1 (NSIS_1): site location, sampling and profile description protocols (19781988). Technical Bulletin, Macaulay Land Use Research Institute, Aberdeen

Lindsay RA, Riggall J, Burd F (1985) The use of small-scale surface patterns in the classification of British peatlands. Aquilo Ser Bot 21:69-79

Loague K, Green RE (1991) Statistical and graphical methods for evaluating solute transport models: overview and application. J Contam Hydrol 7:51-73

Parton WJ, Mosier AR, Ojima DS, Valentine DW, Schimel DS, Weier K, Kulmala AE (1996) Generalized model for $\mathrm{N}_{2}$ and $\mathrm{N}_{2} \mathrm{O}$ production from nitrification and denitrification. Global Biogeochem Cycles 10:401-412

Reynolds B (2007) Implications of changing from grazed or semi-natural vegetation to forestry for carbon stores and fluxes in upland organo-mineral soils in the UK. Hydrol Earth Syst Sci 11:61-76

Saffigna PG, Philips IR (2006) Fertilizers: leaching losses. In: Lal R (ed) Encyclopaedia of soil science, 2nd edn, Vol 1. CRC Press, Boca Raton, FL, p 688-690

Scottish Government (2010) Scotland's Action to tackle climate change. Available at www.scotland.gov.uk/Topics/ Environment/climatechange

Smith J, Gottschalk P, Bellarby J, Richards M and others (2010) Model to Estimate Carbon in Organic SoilsSequestration and Emissions (ECOSSE). User manual. Scottish Executive, Edinburgh, available at https://www. abdn.ac.uk/staffpages/uploads/soi450/ECOSSE\%20User\% 20manual\%20310810.pdf

Smith JU, Smith P (2007) Environmental modelling. An introduction. Oxford University Press, Oxford

Smith JU, Bradbury NJ, Addiscott TM (1996a) SUNDIAL: a PC-based system for simulating nitrogen dynamics in arable land. Agron J 88:38-43

Smith JU, Smith P, Addiscott TM (1996b) Quantitative methods to evalutate and compare soil organic matter (SOM) models. In: Powlson DS, Smith P, Smith JU (eds) Evaluation of soil organic matter models using existing long-term datasets. NATO ASI Series I, Vol 38. Springer-Verlag, Heidelberg, p 181-200

> Smith JU, Smith P, Wattenbach M, Zaehle S and others (2005) Projected changes in mineral soil carbon of European croplands and grasslands, 1990-2080. Glob Change Biol 11:2141-2152

Smith P (2001) Soil organic matter modeling. In: Lal R (ed) Encyclopedia of soil science. Marcel Dekker, New York, NY, p 1-8

Smith P, Smith JU, Powlson DS, McGill WB and others (1997) A comparison of the performance of nine soil organic matter models using seven long-term experimental datasets. In: Smith P, Powlson DS, Smith JU, Elliott ET (eds) Evaluation and comparison of soil organic matter models using datasets from seven long-term experiments. Geoderma 81:153-225

Smith P, Smith J, Flynn H, Killham K and others (2007) ECOSSE: Estimating Carbon in Organic Soils-Sequestration and Emissions. Scottish Executive, Edinburgh

Turunen J, Tomppo E, Tolonen K, Reinikainen A (2002) Estimating carbon accumulation rates of undrained mires in Finland: application to boreal and subarctic regions. Holocene 12:69-80

> Turunen J, Roulet NT, Moore TR, Richard PJH (2004) Nitrogen deposition and increased carbon accumulation in ombrotrophic peatlands in eastern Canada. Global Biogeochem Cycles 18:GB3002 doi:10.1029/2003GB002154

UK Government (2010) Climate change. Available at www.direct.gov.uk/en/Environmentandgreenerliving/The widerenvironment/Climatechange/index.htm

> Vitt DH, Halsey LA, Bauer IE, Campbell C (2000) Spatial and temporal trends in carbon storage of peatlands of continental western Canada through the Holocene. Can J Earth Sci 37:683-693

> Walse C, Berg B, Svedrup H (1998) Review and synthesis of experimental data on organic matter decomposition with respect to the effects of temperature, moisture, and acidity. Environ Rev 6:25-40

Wang ZP, Lindau CW, Delaune RD, Patrick WH (1993) Methane emissions and entrapment in flooded rice soils as affected by soil properties. Biol Fertil Soils 16:163-168

Welsh Assembly Government (2010) Climate change strategy for Wales. http://wales.gov.uk/topics/environmentcountry side/climatechange/tacklingchange/strategy/walesstrategy/ ?lang=en

West TO, Post WM (2002) Soil organic carbon sequestration rates by tillage and crop rotation: a global data analysis. Soil Sci Soc Am J 66:1930-1946

> Whitmore AP (1991) A method for assessing goodness of computer simulations of soil processes. J Soil Sci 42:289-299

Zerva A, Ball T, Smith KA, Mencuccini M (2005) Soil carbon dynamics in a Sitka sprice (Picea sitchensis (Bong.) Carr.) chronosequence on a peaty gley. For Ecol Manag 205: $227-240$ 